\title{
1. Definitions, strategic considerations and subject matter
}

The discipline of strategy is necessitated for our thesis. Strategy is about the deployment of the right tools and in the right way in a given exercise. It is about affording oneself the opportunity to control one's future based on available resources. ${ }^{1}$ Strategy is about planning, method, system and implementation. Controlling the future, when it comes to incorporating foreign law into the domestic legal sphere, means that a predictable result will be achieved.

At this point it is deemed essential for the reader to be familiarised with a number of background notions, which are highly relevant to the analysis. In turn, such notions as harmonisation of laws, convergence and convergent legal instruments will be explored.

\section{HARMONISATION}

Harmony is a state of affairs in which otherwise disjointed matter comes to be conjoined. Harmonisation is the act and the process of effecting harmony.

\section{Harmonisation of Laws}

Harmonisation of legal systems amounts to the assimilation of legal standards and norms through the massive diffusion and transplantation of foreign norms. Harmonisation of specific laws (as opposed to harmonisation of whole legal systems) may necessitate the deployment of as little as a single transplant amongst different legal systems. Harmonisation of laws is the act and the process of effecting the assimilation, convergence, uniformisation and approximation of different legal worlds and realities. In the context of legal systems, the act of harmonisation constitutes the importing of foreign standards into a

1 Cf. M. McKeown, The Strategy Book (2nd edn, FT Publishing, 2015). 
legal system, thereby creating a new legal order of things in the domestic sphere.

Previously, a 'hard'2 definition of harmonisation of laws arose in 1966, as was found in the United Nations' Resolution 2205 (XXI). It was said there that 'promoting the adoption of international conventions, uniform laws, standard contract provisions, general conditions of sale, standard trade terms and other measures' ${ }^{3}$ would remove divergencies as between the laws of different states. This definition seems to be slightly out-of-date now, even though it holds a certain validity from the purely international law point of view.

Normally, legal harmonisation projects are highly purpose-driven initiatives. For instance, the previous efforts to harmonise "the law of trade was sought on the presumption that it enabled international trade and not simply for the sake of harmonising and unifying laws'. ${ }^{4}$ At other times, however, these purpose-driven initiatives may be the result of a wider integration agenda, an integration agenda between States.

Harmonised law can take a plethora of forms. Conventions, Rules, Model Laws, Recommendations, Legal Guides, Legislative Guides, Directives, Regulations are indicative forms which harmonised legislation may take. Naturally, the variability of harmonised tools used depends on the purpose behind the harmonised norm to be created and implemented.

\section{CONVERGENCE}

Convergence of laws is an affiliated idea to harmonisation of laws. Convergence of laws is a process as well as a result to be achieved. If so, this is the result and the process of the coming together of different legal systems, albeit in certain areas of law. Convergence of laws is epitomised by the following: ${ }^{5}$

2 The term belongs to Block-Lieb and Halliday. See S. Block-Lieb and T. Halliday, 'Harmonization and Modernization in UNCITRAL's Legislative Guide on Insolvency Law' (2007) 42 Texas International Law Journal 481, 494.

3 UN General Assembly Resolution 2205 (XXI), UN GAOR, 21st Session, Supp. No. 16, UN Doc. A/6594 (17 December 1966), Part I.

4 Block-Lieb and Halliday, 'Harmonization and Modernization in UNCITRAL's Legislative Guide on Insolvency Law', n. 2 above.

A more European definition of convergence would confine the term to the coming together of continental civil law with non-continental common law. See e.g., S. Van Erp, 'Different Degrees of Convergence: A Comparison of Tort Law (Example: Fairchild v. Glenhaven Funeral Services) and Property Law' (2002) 6(3) 
for good reasons and with particular circumspection, ${ }^{6}$ with or without reservations, national legal systems can and should gradually ${ }^{7}$ converge into one another and into wider, extra-national, legal formations. ${ }^{8}$

Elaboration on the above definition would suggest that legal harmonisation projects are not empty political vessels, which are concluded on mere political agreement. They must come with a clear purpose. A costs and benefits analysis must invariably define them. The obvious exception to such an analytical pattern would probably be harmonisation projects on human rights, which should be taken to be worthy of application on the basis of convergence of political principle alone (as opposed to following a costs and benefits analysis, as in the case of economic law harmonisation initiatives). Convergence of laws does not have to be perfect. The degree of convergence and harmonisation between different sovereign States largely depends on the political will of the participants in a circle of convergence. Reservations and opt-outs ought to be possible from the outset. However, it is also contemplated that the participants in a legal harmonisation circle should ultimately derive greater benefit by their greater commitment to harmonised standards (as they would form a block of legal uniformity, thereby increasing freedom of trade, respect for human rights, and so forth). In addition, legal harmonisation projects do not have to be achieved in a spasmodic fashion or at once. A holus bolus approach is far from ideal. Legal systems must be able to discuss, digest and implement harmonised standards in a gradual fashion. The exercise of convergence of legal systems normally has to take place in a gradual fashion. The more sudden the moves in favour of convergence of legal standards, the greater the likelihood for legal systems to resist complying with such standards. The greater the resistance of legal systems to conform with harmonised standards, the greater the likelihood for the legal harmonisation projects to fail. Harmonised standards must, therefore, be carefully planned, carefully executed and gradually implemented.

Convergence, in literal terms, could be perceived as the movement directed toward or terminating in the same point. ${ }^{9}$ Such a point is the point of convergence. For legal purposes, however, convergence must be both a

Electronic Journal of Comparative Law (October) 1; the article is available at www. ejcl.org/63/art63-4.doc.

6 U. Mattei, Comparative Law and Economics (Ann Arbor, MI, University of Michigan Press, 1998, reprinted in 2004), pp. 17-19.

7 B.S. Markesinis, The Gradual Convergence (Oxford, Clarendon Press, 1994).

8 A.E. Platsas, The Convergence of Laws: A Typology of Implementation Models and Factors (Ph.D. Thesis, Trinity College, University of Dublin, 2007), p. 14.

9 'That which "converges" is that which purports to reach the same point': 
process and a result to be achieved. In practical terms, the legal point of convergence might be nothing more than the meeting of minds on a given legal matter, which is followed by political agreement and legal implementation. There are many examples of the close relationship of legal convergence and political convergence. Political Europe is a good example of considerable political integration and legal convergence in the form of the European Union; in North America, NAFTA ${ }^{10}$ effectively amounts to legal and political consensus on certain economic principles between the United States, Canada and Mexico. Another example of political consensus (albeit with limited legal results beyond the declaratory) is the ASEAN, ${ }^{11}$ an organisation of economic co-operation in South East Asia. Other notable examples of regional organisations engaged with the harmonisation of regional economic standards are ECO, ${ }^{12}$ MERCOSUR, ${ }^{13}$ USAN, ${ }^{14}$ EAEU, ${ }^{15}$ CARICOM $^{16}$ and ACS. ${ }^{17}$

P. Legrand, 'Public Law, Europeanisation, and Convergence: Can Comparatists Contribute?' in P. Beaumont, C. Lyons and N. Walker (eds), Convergence and Divergence in European Public Law (Oxford/Portland, OR, Hart Publishing, 2002), p. 226.

10 North American Free Trade Area. The North American Free Trade Agreement, which comprises Canada, Mexico and the United States, is (as its name suggests) a free trade area, but unlike the EU it provides only for free movement of goods and services. No actual provision is made in the agreement itself in relation to free movement of capital and persons as in the case of the EU. Additional objectives of NAFTA within this free trade area are: the promotion of conditions of fair competition; the increase of investment opportunities; the effective protection and enforcement of intellectual property rights and the creation of a framework for further co-operation to enhance the benefits of the Agreement.

11 Association of South East Asian Nations. The Association of South East Asian Nations has a population of more than 550 million people and is one of the three main political and economic players in the Pacific region along with China and Japan. The ASEAN Declaration 1967 states that the aims and purposes of the Association are: (i) to accelerate the economic growth, social progress and cultural development in the region through joint endeavours in the spirit of equality and partnership in order to strengthen the foundation for a prosperous and peaceful community of Southeast Asian nations and (ii) to promote regional peace and stability through abiding respect for justice and the rule of law in the relationship among countries in the region and adherence to the principles of the United Nations Charter. In 1995, the ASEAN Heads of State and Government re-affirmed that 'Cooperative peace and shared prosperity shall be the fundamental goals of ASEAN'.

12 Economic Cooperation Organisation (in Asia).

13 Southern Common Market (in South America).

14 Union of South American Nations (in South America).

15 Eurasian Economic Union (in Eurasia).

16 Caribbean Community (in the Caribbean).

17 Association of Caribbean States (in the Caribbean). 


\section{Formal Convergence}

Legal convergence, in more precise terms, especially formal legal convergence, came to be known amongst academicians following the work of Markesinis in this field. Of course, that is not to say that the idea of convergence did not pre-exist. On the contrary, the idea seems to come from the distant past. In this respect, one notes that Plato has been the leading theoretician who has dealt with the philosophical fundamentals of the idea of the one. ${ }^{18}$ As stated, Markesinis' work in the field of legal convergence has been quite influential in the subject area. ${ }^{19} \mathrm{He}$ and a number of European scholars suggested that harmonisation of laws takes a variety of forms; ${ }^{20}$ these include:

- academic work in universities;

- legal practice;

- international Conventions;

- EU Directives; ${ }^{21}$ and

- case law of the Court of Justice of the European Union (CJEU).

In the essence of the matter, formal convergence of laws may be the approximation of laws at a primary stage. Such approximation may further

18 The philosophical underpinning of convergence per se is found in the works of Plato and in particular in his theory of 'One-Over-Many'. See e.g., Rep. 596a or Phaedo 100c-d (see 'Introduction: ideological nexus of the law convergence thesis' herein for more on this); see also P. Legrand, 'The Same and the Different' in P. Legrand and R. Munday (eds), Comparative Legal Studies: Traditions and Transitions (Cambridge, Cambridge University Press, 2003), p. 299. Traditionally, however, it is Cicero who first discussed the idea of a universal, natural law, which would apply in time and space without frontiers, the only limits of which can be set by the divine. See Cicero, De Republica, III, xxii, 33. In more recent times, one of the fathers of modern comparative law, Edouard Lambert, has also been a great supporter of the idea of convergence, even though he would speak of 'uniform and international laws' rather than convergence per se. See E. Lambert, 'Sources du droit compare ou supranational: législation uniforme et jurisprudence comparative' in Recueil d'études sur les sources du droit en l'honneuer de François Gény (Paris, Sirey, 1934), vol. III, p. 502. However, the classical work on cultural convergence and therefore the forerunner of Markesinis' legal convergence is that of Clark Kerr, Industrialism and Industrial Man (Cambridge, MA, Harvard University Press, 1960). In this work he argues, inter alia, that the global convergence of cultures is the outcome of industrialisation processes.

19 Markesinis, The Gradual Convergence, n. 7 above.

20 Ibid. 21. See also B. de Witte, 'The Convergence Debate' (1996) 3 Maastricht Journal of European and Comparative Law 105.

21 It is quite peculiar that Prof. Markesinis referred at the time to EC Directives 
generate uniform legal standards, through the letter and implementation of international conventions or treaties, at a secondary stage. ${ }^{22}$ On occasion, a uniform approach may cause greater irritations to the domestic legal order than an approximating approach. This has been observed in Europe, since even approximating legal mechanisms such as Directives cause certain friction in practice. ${ }^{23}$ However, even if one deploys a model which includes directive forms of harmonised law and regulatory forms

only, as opposed to EC Directives and Regulations, Regulations also being a prima facie instrument of legal harmonisation/convergence in Europe. Perhaps this has been so, as Regulations are, in any case, expected to directly apply throughout the EU Member States, whilst Directives have to be implemented by way of specific national legislation, though the policies therein have to be achieved throughout the States affected. Alternatively, Markesinis may have used the word 'Directives' when he meant Directives and Regulations.

22 Thus, one of the most fundamental taxonomies of convergence is between an approximating model and a uniformist model thereof. Another distinction is that between an absolute/total model and a relative/partial model of convergence (opt-in/opt-out model). A third distinction is that between esoteric level convergence, i.e. convergence that touches upon the domestic rules of the system e.g. when an EU Regulation applies against an old domestic rule of a legal system and changes it, and exoteric convergence, i.e. convergence that signifies alignment of principle between legal systems, e.g. the various human rights treaties. The latter example becomes problematic, however, when such international instruments lead to modifications of domestic human rights law. Cappelletti distinguishes the models of convergence by theory; his analysis includes seven models: (i) return to ius commune theory; (ii) legal evolution theory; (iii) natural law theory; (iv) law as superstructure theory; (v) international transactions theory; (vi) international integration theory; (vii) simplicity and certainty theory. See J.H. Merryman, 'On the Convergence (and Divergence) of the Civil Law and the Common Law' in J.H. Merryman (ed.), The Loneliness of the Comparative Lawyer and Other Essays in Foreign and Comparative Law (The Hague/London/Boston, MA, Kluwer Law International, 1999), p. 17 et seq. This was reprinted from M. Cappelletti (ed.), New Perspectives for a Common Law of Europe (Leyden, Sijtoff, 1978), p. 195. Finally, Nottage argues that convergence can be divided between a 'Rules-Plus' kind of convergence (or convergence on rules and the law in the books) and a 'Law in Context' kind of convergence (or convergence on law in action). See L. Nottage, 'Comment on Civil Law and Common Law: Two Different Paths Leading to the Same Goal' (2001) 32 Victoria University of Wellington Law Review 843, 847.

23 On this, see the scepticism of Gunther Teubner in relation to the implementation of a non-uniformist instrument of law, which should not normally cause particular friction in its implementation: Council Directive 93/13/EEC of 5 April 1993 [1993] OJ L95/29, 21 April 1993. Apparently it did. As such, a Directive should not have caused friction in the body of British contract law, since it would otherwise allow the British to choose the actual means of its implementation. See G. Teubner, 'Legal Irritants: Good Faith in British Law or How Unifying Law Ends Up in New Divergences' (1998) 61 Modern Law Review 11. 
of harmonised law, issues might still arise. In a country like the United Kingdom, a legal order comprising common law traditions predominantly, it has been attitudes and phobias which separate(d) this country from continental Europe. ${ }^{24}$ Remarkably, the United Kingdom is not that far apart from other European jurisdictions, when it comes to legal problems, solutions and methodology. ${ }^{25}$ Yet, one notes that the close-to-prophetic words of Markesinis on this subject (as to the reluctance of a leading European legal order such as the United Kingdom to participate in the EU circle of legal convergence) signifies nothing more than the political phobias and attitudes of the past. The victory of the anti-EU voices in the 2016 UK Referendum is only illustrative of these neo-traditional voices coming to the surface in the political United Kingdom. Currently, similar voices, voices advocating the return to a more nation-oriented Europe, are on the rise not just in the United Kingdom but also in other parts of Europe.

Broadly speaking, the ideal of legal convergence presents us with a rather positive state of affairs. This would stand for a new cosmopolitan legal order of things. Goethe put this elegantly as follows:

Gott grüss Euch Brüder

Sämtliche Oner und Aner

Ich bin Weltbewohner

Bin Weimaraner. ${ }^{26}$

In more concrete terms, the phenomenon of legal convergence is mostly desirable. Disadvantages may well exist in a circle of legal convergence but it would seem that the advantages by far outweigh the disadvantages, the latter mainly relating to political process rather than legal reality. Thus, the obvious drawbacks to a legal convergence exercise have to do with onerous political involvement in the creation of harmonised legal standards; manipulation of smaller states in such a law-making process; and, of course, issues of transposition and implementation. As to the obvious advantages and good reasons, when it comes to pursuing convergence of legal standards, one notes a plethora of such, ${ }^{27}$ relating to the following:

24 Markesinis, The Gradual Convergence, n. 7 above, at 1.

25 Ibid.

26 ('I greet you, brothers-Partisans of various "isms" and "slogans": As for me I'm a world citizen, As well as Weimarian!'). J.W. von Goethe, 'Zahme Xenien' in Sämtliche Werke (Berliner Ausgabe, Bournal, 2: Teil, Poetiische Werke, A. Lenhoff (trans.)), p. 687, as quoted in Markesinis, n. 7 above, at 1.

27 See L. Mistelis, 'Is Harmonisation a Necessary Evil? The Future of Harmonisation and New Sources of International Trade Law' in I. Fletcher, 
(1) the Platonic One (postulation of universals); ${ }^{28}$

(2) the fact that there is overall unity of thought in the human race, something which comes in agreement with the calls of Hegelian Idealism; ${ }^{29}$ according to this approach, the unity of thought in the human race ought to generate, by extension, unity of legal thought (especially when it comes to legal results): ${ }^{30}$ 'There is no such thing as "German" physics or "British" microbiology or "Canadian" geology'. ${ }^{31}$ This comes in agreement with the fact that knowledge and science as a whole are unconfused, indivisible and inseparable ${ }^{32}$

L. Mistelis and M. Cremona (eds), Foundations and Perspectives of International Trade Law (London, Sweet \& Maxwell, 2001), pp.4-27 and in particular pp.20-2. 28 See $\mathrm{n} .18$ above.

29 Hegel's account of idealism can be seen as the idea that the being is ultimately comprehensible as an all-inclusive whole. See e.g., R.B. Pippin, Hegel's Idealism: The Satisfactions of Self-consciousness (Cambridge, Cambridge University Press, 1989).

30 The locus classicus on this is the work of K. Zweigert. See K. Zweigert, Des solutions identiques par des voies différentes (Quelques observations en matière de droit comparé)' (1966) 18 Revue internationale de droit comparé 5. For extracts in English, see K. Zweigert, 'Different Paths to Identical Solutions: Some Comments on Comparative Law' in V. Gessner, A. Hoeland and C. Varga (eds), European Legal Cultures (Aldershot, Dartmouth Publishing Co. Ltd, 1996), pp. 160-4. See also Markesinis, n. 7 above, at 1. 'On the truth of this premise and the promise it holds for comparative lawyers', see more recently B.S. Markesinis, Comparative Law in the Courtroom and Classroom: The Story of the Last Thirty-Five Years (Oxford/Portland, OR, Hart Publishing, 2004), p.36. In the same reference it has been argued that "the most "basic issues" pop up in all systems and are not excluded by the different histories or other peculiarities of each of them, making mutual borrowing possible'.

31 K. Zweigert and H. Kötz, An Introduction to Comparative Law (3rd edn, Oxford, Oxford University Press, 1998), p. 15. The thesis of the unity of science comes in agreement with the modern Vienna Circle of philosophy. For writings on the unity of science, see e.g., L. von Bertalanffy, 'An Outline of General System Theory' (1950) 1 British Journal of the Philosophy of Science 134, at 134-65; P. Oppenheim and H. Putnam, 'Unity of Science as a Working Hypothesis' (1958) 2 Minnesota Studies in the Philosophy of Science 3, as reprinted in R. Boyd, P. Gasper and J.D. Trout (eds), The Philosophy of Science (Cambridge, MA/London, MIT Press, 1991), pp. 405-27. Cf. J. Fodor, 'Disunity of Science as Working Hypothesis' (1974) 28 Synthese 77, reprinted as 'Special Sciences' in R. Boyd, P. Gasper and J.D. Trout (eds), The Philosophy of Science (Cambridge, MA/London, MIT Press, 1991), pp.429-41, and more recently, J. Fodor, 'Special Sciences: Still Autonomous After All These Years?' (1997) 11 Philosophical Perspectives 149.

32 On this see Plato's theory of the Forms. The characteristics and functions of the Forms according to Plato are: (i) unchangeable (Phaedo 78c10-d9); (ii) eternal (Phaedo 79d2); (iii) intelligible, not perceptible (Phaedo 79a1-5); (iv) divine (Phaedo 80a3, 80b1); (v) incorporeal (Phaedo passim); (vi) causes of being ('The 
this being the case, it should be noted that the legal harmonisation thesis is normally about convergence of national laws in non-culturally specific areas of law; 33

(3) there already is unity from within ${ }^{34}$ in the common law sphere and the civilian law sphere;

(4) it is inherent in the harmonisation thesis that harmonisation lifts barriers and creates a level playing field for economic actors, thereby promoting an environment of globalisation; ${ }^{35}$

(5) it is axiomatic that supranational, extra-national and international forms of law do what their name suggests: they cater for supranational, extra-national and international problems of law; thus, harmonised rules serve harmonised policies; ${ }^{36}$

(6) it is possible that the adoption of harmonised standards may actually lead to the sophistication of domestic legal standards;

(7) 'neutral law' solutions are preferred so that newly created harmonised norms are compatible with the rules of the systems affected; ${ }^{37}$

one over the many') (Phaedo 100c); (vii) unqualifiedly what their instances are only with qualification (Phaedo 75b).

33 It is possible to agree on harmonised laws by maintaining a certain degree of legal deviations due to socio-legal considerations. See Chapter 5.

34 Legrand admits this. See P. Legrand, 'European Legal Systems are Not Converging' (1996) 45 International and Comparative Law Quarterly 52, 78, where he clearly implied this by the following: 'the Civilian lawyer will never understand the Common law experience and the Common lawyer will never understand the Civilian law experience'. Legrand, thus, understands that there is unity from within the common law world and the civilian law world.

35 For the locus classicus with regard to the popularisation of the term 'globalisation' see T. Levitt, 'The Globalization of Markets' (1983) 61 Harvard Business Review 92; on a definition of the term, see also A. Giddens, The Consequences of Modernity (Cambridge, Polity Press in association with Blackwell, 1990), p. 64. On the promotion of globalisation through convergent law, see J.A. Spanogle, Jr., 'American Attorneys' Use of International and Comparative Legal Analysis in Everyday Legal Practice' (1993) Wake Forest Law Review 1. Spanogle argues that globalisation of the markets requires globalisation of the (legal) rules too. See also an article by the author of this monograph in relation to the role of comparative law as the ideal method for reaching convergence amongst the financial systems of the world in the environment of globalisation, A. Platsas, 'Comparative Law as the Ideal Means of Convergence of the National Financial Systems in the World of Globalisation' (2002) 7(2) Coventry Law Journal (December) 53.

36 As in Aristotle's 'rules serve purposes' structure by way of analogy. See Aristotle, Nichomachean Ethics $\mathrm{V}$, x.

37 Moens and Biffot refer 'to a tendency of the world's legal families to embrace a common intellectual framework for the consideration and resolution of problems'. See G.A. Moens and R. Biffot, 'Convergence of the Legal Systems in the 21st Century' in G.A. Moens and R. Biffot (eds), The Convergence of 
(8) the adoption of a single global or regional legal standard leads to the proliferation of different laws from different countries in the same area of law; consequently, this makes the need for conflict of law solutions obsolete;

(9) legal systems, acting in unison with common and harmonised policies, acquire a greater degree of political power for themselves (e pluribus unum). Their convergence then becomes like that of the strong rope consisting of fibres; a rope, which 'does not get its strength from any fibre [any convergent legal system for the purposes of our analysis], which runs through from one end to the other, but from the fact that there is a number of fibres overlapping'; 38

(10) the idea behind legal harmonisation is ultimately about a yearning for simplicity; as Merryman put it: 'the desire for convergence of legal systems merely expresses a yearning for simplicity. It responds to popular discontent with complexity and seeks to impose order where there is untidy diversity . . . it is little more than an expression of frustration at the fact that the world is complicated, disorderly and uncertain'. ${ }^{39}$

Again, the thesis behind the harmonisation of legal systems is not a flawless one. As stated, political manipulation of the harmonised legal norms and the sidelining of smaller and less powerful States during the preparatory stages of harmonised norms may well be a very real possibility. Other drawbacks could be:

(1) what Legrand calls the 'Procrustean bed of sameness';40

(2) harmonisation may obliterate or neglect the cultural, resulting in a state of affairs in which legal-cultural fusionism ${ }^{41}$ prevails;

(3) there may be lack of democratic legitimisation, ${ }^{42}$ the creation of harmonised norm being a highly technocratic exercise (especially in cases of legal convergence occurring on a 'top-down' basis);

Legal Systems in the 21st Century: An Australian Approach (Brisbane, Copyright Publishing, 2002), p. 5.

38 For this excellent philosophical metaphor see R. Rhees, Preliminary Studies for the 'Philosophical Investigations' (2nd edn, Oxford, Blackwell, 1964), p. 87.

39 Merryman, 'On the Convergence (and Divergence) of the Civil Law and the Common Law', n. 22 above, at 27.

40 P. Legrand, 'The Same and the Different' in P. Legrand and R. Munday (eds), Comparative Legal Studies: Traditions and Transitions (Cambridge, Cambridge University Press, 2003), p. 302.

41 Ibid. 303.

42 C. Harlow, 'Voices of Difference in a Plural Community' in P. Beaumont, 
(4) harmonisation projects may well disregard pre-established national practices and traditions (especially the ones which have served well).

In light of the above, it is important that harmonised legal projects do not go too far at too early a stage. This comes in agreement with Markesinis' graduality thesis, with which the author largely agrees. Otherwise, when Legrand advocated ${ }^{43}$ the idea that European legal systems are not converging, he seemed to have committed the mistake of looking for a perfect world of legal convergence in a world of imperfection in human affairs. Practically, Legrand was advocating perfect convergence: a utopia. Such a utopia will never exist, because it will never exist by definition (argumentum ad dictionarium). Thus, perfect harmonisation of legal systems is a utopia. Utopias do not exist. As such, Legrand might be wrong in inferring that the apparent lack of perfect harmonisation of European legal systems constitutes an impossibility for the whole of the convergence exercise between legal systems. Inevitably, however, Legrand might be right about one thing: convergence may well occur at a primary and basic level, such a level operating beyond the deep structures of legal systems which are otherwise to be aligned by harmonised legal norms. Thus, harmonisation of legal systems may occur at a certain legal layer only. Also of interest is the fact that Legrand argued that harmonised norms are ephemeral, contingent and unreliable guides as to how legal systems operate and how their respective lawyers think. He opined that a common lawyer will never be able to understand the civilian legal experience, and vice versa. Yet, there is no such thing as an ad infinitum guarantee with regard to the applicability of harmonised legal standards. Ephemerality of harmonised legal projects thus becomes an irrelevance (if it comes to this). Nor would it matter at this stage of legal history whether a civilian is able to digest the mechanics and the spirit of the common law world (and vice versa).

There is a very straightforward reason for this: harmonised projects, as we came to know them after the end of the Second World War, are still at an embryonic level of their development. In historical terms, the two generations that have passed since the last Great War are a mere detail in the face of humanity's existence. The positive (or, indeed, the negative) effect of legal harmonisation projects is felt after many decades of convergence. The convergence of legal systems is still in the making. Furthermore, the more appropriate question to be asked is whether and

C. Lyons and N. Walker (eds), Convergence and Divergence in European Public Law (Oxford/Portland, OR, Hart Publishing, 2002), pp. 203-5.

43 Legrand, 'European Legal Systems are Not Converging', n. 34 above. 
how our future lawyers (whether common lawyers or civilians) will be able to feel, comprehend and absorb experience from other families of law. Certainly, convergence of legal systems is not a universal cure for all ills in the discipline of law, or, indeed, for all ills which humanity has inflicted upon itself, in the face of human history and the imperfect ways of humanity. Fundamentally, convergence of legal systems, through harmonised standards, is about very precise exercises, whereby legal systems democratically participate in the law-making process of common standards and norms, in order for such norms to create an environment of practicality for commerce, human rights and other significant areas of law for the systems in question. In short, the general goal of convergence of legal systems will occur through specific harmonisation initiatives. As our world steadily moves towards more democratic forms of governance in an increasing number of jurisdictions, one has reason to believe that the whole exercise of convergence will be one which is legitimised. Additionally, let us be clear about this: convergence of laws is about relative and realistic results, which may or may not bring perfect or absolute harmonisation between different legal standards. Ideally, such standards should be wholly harmonised. Yet, for the reasons explained above, the convergence exercise may well be an imperfect one (as opposed to it being an impossible one). Perhaps, then, it would be important for us to perceive the convergence of legal systems as an imperfect exercise the results of which may improve in time. After all, this comes in agreement with a central aspect of the thesis herein: the gradual character of the legal harmonisation thesis. Thus, to maintain that legal systems in Europe do not converge misses the point, and the point is that they do converge, albeit in certain areas only.

Importantly, the question of the possibility of legal convergence through harmonised norms has to be negotiated. First of all, it becomes clear that legal convergence of systems presents us with a very dynamic state of affairs. The likely departure of the United Kingdom by 2020, following the 2016 UK Referendum, from the European Union's main machinery proves the point. Circles of legal convergence add members to them but they may also lose members from them. Our world's interconnectedness, however, allows the flourishing of an environment of convergence of legal norms. Harmonisation of laws 'occurs almost everywhere with bewildering speed and that [the comparatist's] difficulty is to ensure that knowledge [on convergence] is up to date'. ${ }^{44}$ The EU's significant expansions in 2004 and 2007, with the accession of a significant number

\footnotetext{
44 R. Munday, 'Accounting for an Encounter' in P. Legrand and R. Munday
} 
of States, have created a very different legal Union to the one that used to operate in the $1980 \mathrm{~s}$ and the $1990 \mathrm{~s}$. However, the main reason as to why convergence of laws can occur is that it has already been tested in practice. ${ }^{45}$ A second reason as to the possibility of convergence of laws has to do with the fact that such convergence of laws (as in unity of laws) has occurred previously. Whether by sword, as in ancient Rome, stretching many of its laws and imperium from the Middle East to the Strait of Gibraltar, or by peaceful means nowadays, by way of treaties, conventions and other devices of international law, the unification of different legal cultures and systems remains a possibility. Of course, one's argument is not of the following kind: simply because this phenomenon has occurred, it can occur again (ergo hoc propter hoc fallacy). One's argument is that, if conditions $\mathrm{A}, \mathrm{B}$ or $\mathrm{C}$ occurred in the past for situation $\mathrm{X}$, then, if conditions $\mathrm{A}, \mathrm{B}$ or $\mathrm{C}$ re-occur, $\mathrm{X} \pm$ can occur in the future. Thus, the question is not whether convergence of laws can occur. The question is how it is to occur. Ideally, convergence of laws should be a democratic and peaceful exercise. Historical exemplification, however, instructs us in the fact that Roman law prevailed all over what was then the known world by violent and forceful means. It prevailed over many different cultures, even though religious law, for instance, was left to the specific cultural constituencies, which had been subjugated under Roman law. Our analysis, therefore, as to culturalism and the challenges that legal cultures may present to the legal harmonisation thesis should not be too pedantic, as Legrand's analysis was, for instance. ${ }^{46}$

A final element with regard to the possibility of legal harmonisation projects and overall convergence is the move of many nations nowadays towards legal co-ordination and political integration. Such a move is

(eds), Comparative Legal Studies: Traditions and Transitions (Cambridge, Cambridge University Press, 2003), p. 26.

45 Ibid.; R. Zimmermann, Roman Law, Contemporary Law, European Law: The Civilian Tradition Today (Oxford/Portland, Hart Publishing, 2001), p. 129. Zimmermann refers to the example of offer and acceptance in South African contract law, which is 'an anglicized version of an essentially civilian doctrine' (quoting D. Hutchison, 'Contract Formation' in R. Zimmermann and D. Visser (eds), Southern Cross: Civil Law and Common Law in South Africa (1996), p. 173).

46 Legrand, 'European Legal Systems are Not Converging', n. 34 above; cf. A. Watson, 'Legal Transplants and European Private Law' (2000a) 4(4) Electronic Journal of Comparative Law (December) 8; the article is available at www.ejcl. org/44/art44-2.doc. Watson suggests that a European Civil Code is very much possible and that 'conformity of interpretation will be a problem, but one must not exaggerate'. 
driven by the ideas of supranationalism ${ }^{47}$ and internationalism. ${ }^{48}$ Such ideas seem to be quite significant for many of the world's political and legal elites, even though it remains to be seen whether the trend toward political and legal globalisation will continue in the next decades. To offer an example, at the beginning of the 2000s, the European Commission invited the European Parliament and the European Council to create a normative blueprint for European contract law. ${ }^{49}$ Whilst the proposition for such a blueprint remained on paper, it shows the tendency of political elites, at the very least, towards common legal standards in key areas of domestic law, such as contract law. One should also take into account the plethora of international treaties which aim to bring together the standards of various States. Thus, one speaks of a likelihood here (as opposed to speaking of mere possibility) with regard to exercises of legal convergence. Convergence of systems, through harmonised law, is very likely to re-occur time and again in the future, as it did and does (albeit in a number of areas). Hence, the question is not whether the phenomenon of convergence of legal systems will continue, but how to keep pace with the generation of harmonised norms in the world environment.

In the process of legal convergence, one must not neglect the power of political will. Bluntly speaking, lack of political will signifies the death of a harmonised norm to be. Considering the wide-ranging effect ${ }^{50}$ of legal

47 D. Dinan, The Encyclopedia of the European Union (London, Macmillan Press Ltd, 2000), p. 441.

48 C. Holbraad, Internationalism and Nationalism in European Political Thought (New York/Basingstoke, Palgrave MacMillan, 2003), p. 1.

$49 \operatorname{COM}(2001) 398$ final, [2000] OJ C255/1, 13 September 2000.

50 The effect of convergent laws is nowadays felt in the constitutional laws of legal systems in many instances. See, e.g. French Constitution 1958, art. 55 (international law) and art. 88 (EU), as reinforced by the decision of 9 April 1992 on the Maastricht Treaty on the European Union; German Constitution 1949, art. 23, as reinforced by the decision of the Federal Constitutional Court of 12 October 1993 [1994] 1 CMLR 57 on the law ratifying the Maastricht Treaty on the European Union; Greek Constitution 1975, art. 28-I, II and III; Irish Constitution 1937, art. 29(4); and the UK European Communities Act 1972. For Belgium see 1831 Constitution, art. 25bis (art. 34 of the Consolidated Constitution) in conjunction with the judgment of 27 May 1971 by the Hof van Cassatie (Cour de Cassation) in Franco-Suisse Le Ski; for Italy, see 1947 Constitution, art. 11 (transfer of competence to international organisations) in conjunction with Granital Judgment No. 170/84 of 8 June 1984; for Luxembourg, see judgment of the Cour de Cassation of 14 July 1954, Pasicrisie luxembourgeoise, vol. 16, 150; for the Netherlands, see 1983 Constitution, art. 94 (compatibility of domestic provisions with international law); for Denmark, see art. 20 of the Danish Constitutional Act 1953 (delegation of competence to international bodies) in conjunction with the Supreme Court Judgment of 6 April 1998; for Spain, see Constitution 1978 art. 93 (transfer of 
harmonisation projects nowadays, one has to pay due attention to the fact that such an impact is created out of the mobilisation of political forces, lobbies and elites. At a minimum, one has to have the backing of willing political leaderships. As Delmas-Marty has noted, '[t]he objectives of internationalisation are determined above all by political choice'. ${ }^{51} \mathrm{It}$ would be a figment to contemplate that a harmonised project with wideranging implications can proceed on mere technocratic interference, e.g. on the part of legal experts and/or administrators. Perhaps, this could occur in the case of more basic harmonised legal projects, those which operate at the level of mere legal normativity. It is, therefore, contemplated that in the process of a harmonised legal norm coming to life through national measures, something more than a scientific legal committee or an extra-national legal authority may be needed. It is thus opined that such bodies will succeed in their task of bringing harmonised legal norms into the domestic sphere, on the basis that they are characterised by a certain relevant degree of democratic or popular legitimacy. Otherwise, it goes without saying that the Rule of Law in relevant domestic legal orders must be present at all times for the successful transposition and sustainability of harmonised norms into such.

\section{HARMONISED INSTRUMENTS AND APPROACHES}

What makes for a convergent instrument of law? What makes for a harmonised approach in law? There are external and internal characteristics

powers to international organisations); for Austria, see art. 9(2) of the 1929/1945 Austrian Constitution (delegation of competences to international organisations); for Cyprus, see Malachtou v. Armefti (1987) 1 Cyprus Law Reports 207, at 235, etc. For more, see K. Lenaerts and P. Van Nuffel, Constitutional Law of the European Union (2nd edn, R. Bray (ed.), London, Thomson/Sweet \& Maxwell, 2005), pp.678-700. Such recognition, however, came from the Court of Justice of the European Union long before official recognition in the judicial systems of EU Member States. Thus, the effect of convergence between what was then the EU with domestic legal systems has been asserted by extra-national justice prior to domestic recognition of such. See 26/62 Van Gend en Loos [1963] CMLR 105; 6/64 Costa v. ENEL [1964] CMLR 425; 11/70 Internationale Handelgesellschaft [1972] CMLR 255; 106/77 Simmenthal [1977] 2 CMLR 1. An interesting analysis in relation to Van Gend en Loos is provided by Fennelly. See N. Fennelly, 'The Dangerous Idea of Europe? Van Gend En Loos (1963)' in E. O'Dell (ed.), Leading Cases of the Twentieth Century (Dublin, Round Hall Sweet \& Maxwell, 2000), pp.220-36.

51 See M. Delmas-Marty, 'Comparative Law and the Internationalisation of Law in Europe' in M. van Hoecke (ed.), Epistemology and Methodology of Comparative Law (Oxford/Portland, OR, Hart Publishing, 2004), p. 248. 


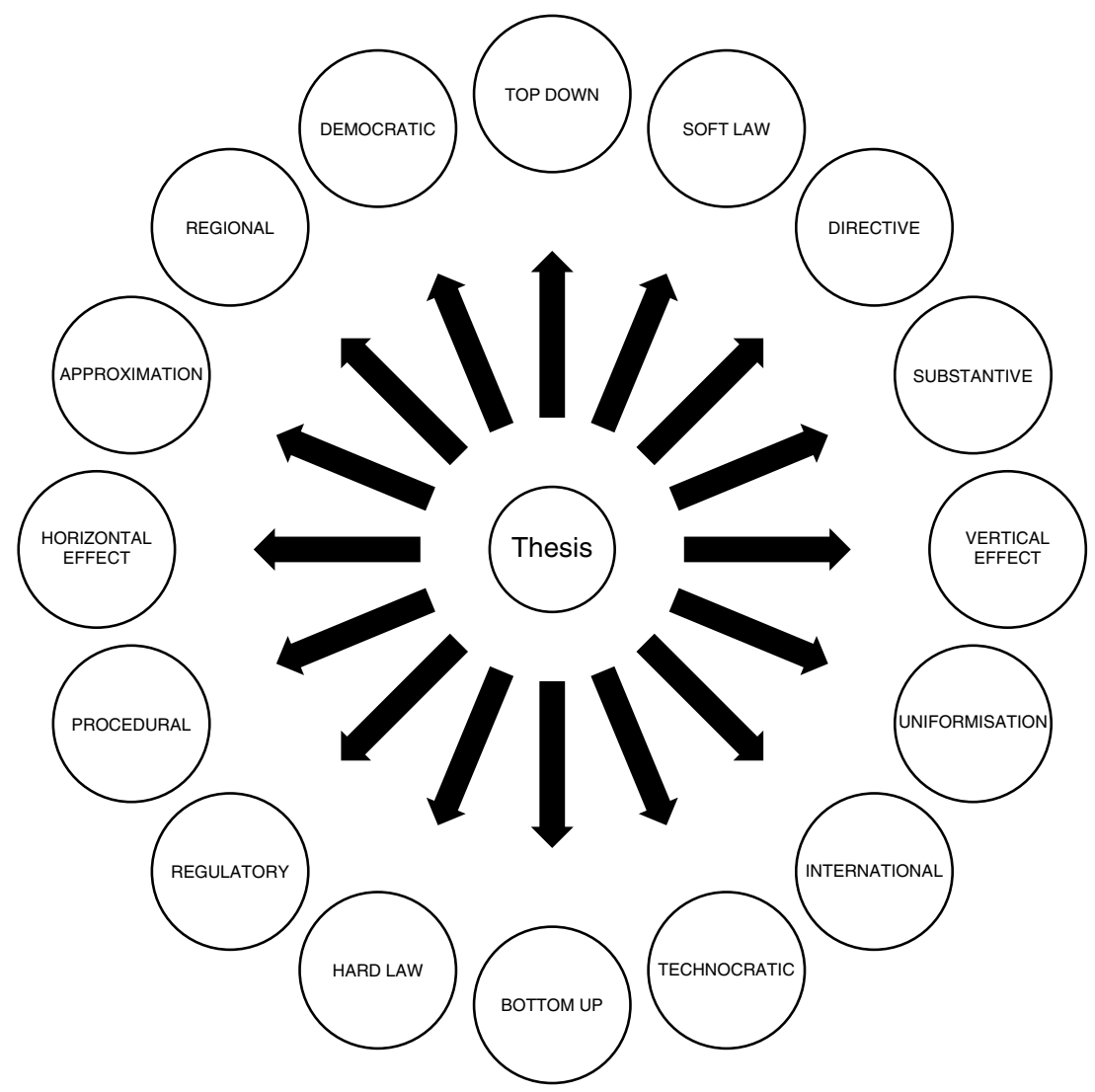

Figure 1.1 Legal geometry of the harmonisation thesis

as to what makes for such an instrument of law and such an approach in law. Perhaps, we could define convergent instruments of law as having their own internal logic, those having internal characteristics vis-à-vis the convergence exercise. So too, we could define harmonised approaches in law as ones having their own external logic, those having external characteristics vis-à-vis the convergence exercise. Figure 1.1 attempts to highlight both the instruments of law and the particular approaches which the legal harmonisation exercise may follow.

\section{Convergent Instruments of Law}

As a whole, there are two types of regulation at the abstract level, when it comes to harmonised norms: norms of a regulatory nature and norms 
of a directive nature. The overwhelming majority of international law instruments (whether at the global or at the regional level) seem to operate as regulatory instruments of law. In Europe, however, Regulations and Treaties clearly constitute regulatory instruments of law, whereas Directives are, as their name suggests, directive instruments of law.

It is important for one to appreciate the relevant alignment techniques, the reason being that the precise nature of the convergent instrument of law may well define the ways in which such an instrument is to be implemented in the national or sub-national sphere. At this point one is reminded of the fact that at the level of abstraction even sub-national legal entities may have to converge, i.e. harmonise their legal standards to national standards, e.g. at federal and confederative level.

First, we shall examine a regulatory instrument of law, the EU Regulation. The EU Regulation is of interest in that this is the most dynamic form of EU law applicable in Europe. This normally regulates a problem in the particulars of national laws or commences a new policy in a given area of law for EU Member States. As compared to EU Treaties, a Regulation is a secondary form of law, yet it is perceived as the most effective, in that it concretises the more abstract spirit of EU treaty law. Under Article 288 of the Treaty on the Functioning of the European Union (TFEU):

A regulation shall have general application. It shall be binding in its entirety and directly applicable in all Member States.

By 'direct applicability' is meant, amongst other things, that Member States will have no discretion to deviate from the letter of the Regulation or omit the implementation thereof. The EU Regulation is, therefore, selfexecuting. ${ }^{52}$ Unlike EU Directives, an EU Regulation is normally made (as opposed to it being issued). ${ }^{53}$

Secondly, examining a directive instrument of harmonised law, the EU Directive, it becomes clear from the outset that Directives are rather peculiar creatures of law. On the one hand, they seem to have certain of the characteristics of what one calls 'model laws'; on the other hand, unlike model laws, they are binding. A Directive is, thus, binding in its goals and objectives, whilst it is not binding when it comes to the means of transposition and implementation. In other words, a Directive normally

52 See e.g., Consorzio del Prosciutto di Parma v. Asda Food Stores Ltd [1999] 1 CMLR 696, in which the English Court of Appeal ruled, inter alia, that a Regulation did not have direct effect, since it was not sufficiently clear and precise and itself indicated that it was not intended to have direct effect.

53 See e.g., TFEU, Arts 46, 109, 132. 
allows EU Member States a considerable degree of manoeuvrability when it comes to the tools of implementation. Here, the goals matter more than the execution. It is taken as a presupposition, however, that the internal legality of operations in the implementing Member States will be maintained at all times. Normally, Directives offer a more complex path of implementation than Regulations would. There are normally four stages of implementation of Directives, as follows:

(1) communication of the Directive's legal information to Member States;

(2) transposition of the Directive's goals and objectives (e.g. through legislative measures);

(3) application of the Directive in concreto (e.g. through administrative acts and/or by application of transposing legislative measures); and

(4) enforcement of the Directive (e.g. primarily through administrative acts and/or secondarily judicial enforcement).

Unlike EU Regulations, an EU Directive is normally issued (as opposed to it being made). ${ }^{54}$ Also, unlike EU Regulations, which generate so-called direct effect (depending, of course, on their wording, clarity of meaning and whether a Member State is required to bring about state action as a requirement of their implementation), the EU Directive (since it almost invariably requires additional legislative and administrative measures on the part of the Member State) does not necessarily present itself with direct effect. The exception to this is the protection of certain rights of individuals, when the text of the communicated Directive is sufficiently clear and precise and despite the fact that the Member State may not have transposed it. ${ }^{55}$ In this case, even EU Directives are taken to have direct effect. Overall, the lack of direct effect of Directives is the result of their very nature. It has been argued, for instance, that such a type of law tends to be imprecise, vague and rather insufficiently defined due to its framework nature. ${ }^{56}$

Moreover an EU Directive may be problematic in itself, when it comes to its implementation. Prechal has previously put it very elegantly as to why this may well be the case:

Person A sends person B to buy something for dinner. A could simply say: 'Buy something for dinner'. On the other hand, A could also say: 'Buy some pasta, sauce and wine' or 'Buy tagliatelle, pesto and Chianti'. A could also send B to

54 See e.g., TFEU, Arts 46, 52, 53, 59, 115.

55 See e.g., C-41/74 Van Duyn v. Home Office (CJEU, 1974).

56 See e.g., Gibson v. East Riding of Yorkshire Council, The Times, 6 July 2000. 
the Italian shop on the corner for the tagliatelle and pesto and to the wine merchant on the other corner for the Chianti etc. Finally, it may happen that B has nothing to do other than to get there. And even in this respect it is conceivable that A says: 'Take the car'. In other words, one situation may involve a distinction between the result on the one hand and the means to realise it on the other, while in another situation both these facets become the result. ${ }^{57}$

Thirdly, federal laws, whilst operating at the level of the nation, are very interesting from the legal harmonisation point of view. Federal laws in the United States (and in other countries) constitute the second highest order of law (after the US Constitution). In case of a clash between the US Constitution and US federal legislation, the Constitution prevails and a finding of unconstitutionality is the case. Under Article I(1) of the US Constitution, it is the US Congress (i.e. the House of Representatives and the Senate) that enacts federal legislation. Nonetheless, Amendment X of the Constitution suggests that the subjects of the US federation, i.e. the States and the people, are reserved powers to legislate, if the Constitution itself does not prohibit such or does not delegate these powers to the federation itself. Also, a federal statute becomes normally and automatically applicable from the moment the US President signs it. The President may or may not veto it, however. If the President does, the statute may still become federal law, if a two-thirds majority votes in its favour in both chambers of Congress. EU Regulations and US federal Acts of Congress can usefully be compared. Whereas the former apply to a number of sovereign Member States, whilst the latter apply to non-sovereign States, the parallels between the two are obvious: thus, they both normally apply throughout their jurisdictions (i.e. the totality of the US States and the totality of EU Member States); they both are normally self-executing; and neither EU Regulations nor US federal Acts of Congress normally offer discretion to their addressees. In effect, US federal Acts of Congress are an internal form of legal harmonisation, that is, they bring US States closer to one another but also harmonise the law of the States to US federal law.

Fourthly, model laws, especially at the international law level and in the United States, are prototypical laws. These are laws which may bring about the harmonisation of different legal systems. However, a model law may never transform into law at all. Take, for instance, the American Model Employment Termination Act of 1991. This was a model law which was drafted by the Uniform Law Commissioners but it did not become law in any US State. A model law may be drafted by a variety of organisations

57 S. Prechal, Directives in European Community Law: A Study of Directives and Their Enforcement in National Courts (Oxford, Clarendon Press, 1995), pp. 16-17. 
and individuals. One of the more classic examples of a leading model law is the UNIDROIT Principles of International Commercial Contracts. Another leading model law example is the UNCITRAL Model Law on International Commercial Arbitration. It is to be stressed that the organisations $^{58}$ issuing model laws do not hold legislative competence or authority per se. However, they are instrumental in the harmonisation and modernisation of world laws. For instance, UNCITRAL started as an organisation generally aiming to harmonise and unify commercial law, whereas, in more recent times, it also saw itself as an organisation for harmonising and modernising this type of law. ${ }^{59}$

Fifthly, one also notes a particular form of law, a sui generis type of legislation, so-called uniform laws in the United States. These are prototypical laws, just like model laws, which primarily aim to bring about uniformity from State to State in the United States, by way of aligning differences that occur between them. The American Law Institute in conjunction with the National Conference of Commissioners have previously drafted and proposed the leading example of commercial legislation in the United States, the Uniform Commercial Code (UCC) 1952. One of the aims of the UCC has been to 'make uniform the law among various jurisdictions' (i.e. various States) ${ }^{60}$ Yet, uniform laws can bring about other positive effects: they may bring about simplification, clarification and modernisation of pre-existing and diverse law. ${ }^{61}$ It is the case that uniform laws in the United States have been particularly successful there. The UCC, for instance, one of the success stories of model uniform law-making in the United States, has been adopted by 49 States, the District of Columbia, and partially by the State of Louisiana.

Sixthly, the most well-known example of harmonised law, at the international level, are, of course, international treaties. At this point, it should be noted that not all treaties are harmonising instruments of law. ${ }^{62}$ When it comes to their categorisation, treaties are either bilateral

58 Model laws in international law are produced by such organisations as UNIDROIT, whereas model laws in the United States are issued by one of the following: the American Law Institute, the National Conference of Commissioners on Uniform State Laws, the American Bar Association and the Council of State Governments Committee on Suggested State Legislation.

59 Block-Lieband Halliday, 'Harmonization and Modernization in UNCITRAL's Legislative Guide on Insolvency Law', n. 2 above, at 511.

60 As in s. 1-102(2)(c) UCC 1952 (as amended).

61 As in s. 1-102(2)(a) UCC 1952 (as amended), for instance, which sought 'to simplify, clarify and modernize the law governing commercial transactions'.

62 Thus, note that the fact that an international treaty is an international treaty does not automatically make it a 'convergent instrument of law'. The typical 
or multilateral. The former category is one which speaks for itself. The latter category is interesting, in that the fact that a treaty purports to have universal effect ${ }^{63}$ does not mean it will have universal effect. So too, even if an instrument of international law is perceived as universal, this does not make it universal. The typical example here is the United Nations (UN) Declaration of Human Rights 1948. Aside from the fact that this is a declaratory piece of soft law legislation, one certainly questions the applicability of the Declaration throughout the world, in addition to the fact that human rights law is a particularly challenging area of law, when it comes to genuine universal understandings thereof. Beyond this, when it comes to defining an international treaty, it has been said that an international treaty is 'a written agreement, governed by international law, concluded between two or more states, or other subjects of international law, possessed of treaty making capacity'. ${ }^{64}$ International lawyers divide such treaties into private international law treaties and public international law treaties. The former category deals with the rights and duties applicable to citizens of different states toward one another; the latter involves the rules applicable between sovereign States. An example of a public international instrument is the UN Charter 1945, whereas an example of private international law would be the UN Convention on Contracts for the International Sale of Goods 1980. The harmonisation scholar also notes that different countries have different constitutional mechanisms, when it comes to the transformation of an international treaty into domestic law. The classic division between monist systems of law and dualist systems of law is thus observed. According to monism, one speaks of a doctrine whereby national and international law form a unity; they are perceived as a single whole and as the same conceptual structure in which international law normally takes precedence. France, Greece and Holland would be constitutional orders which subscribe to the school of monism in international law matters. Practically, this would mean that in these countries, once obligations of international law are assumed, they

example here would be a peace treaty; despite the fact that such an instrument is indeed an international instrument of law, it does not necessarily affect the inner legal workings of contracting States; therefore, such an international treaty is not necessarily a convergent instrument of law.

63 For an example of a universal type of law see e.g., J.C.M. Willens, 'The Children's Law of Nations in the Trias Pedagogica' in J.C.M. Willens (ed.), Developmental and Autonomy Rights of Children: Empowering Children, Caregivers and Communities (Antwerp/Oxford/New York, Intersentia, 2002), pp. 71-2 (para. 2.2: the Children's Law of Nations binds all states, both rich and poor).

64 L.B. Curzon, Dictionary of Law (6th edn, Harlow, Longman, 2002), p. 426. 
take precedence over national law. Dualism is different. It actually divides law into the domestic sphere and the international sphere. By doing so, it proceeds further by implying that, if the international norm is to enter the domestic sphere and be recognised therein, certain domestic legislative steps must be followed. ${ }^{65}$ This is the approach in a number of countries, such as Ireland, ${ }^{66}$ the United Kingdom ${ }^{67}$ and the United States, ${ }^{68}$ even though in the latter case the traditional approach was once a monist one. ${ }^{69}$

\section{Legal Transplants}

A transplant is the transfer of a rule, system or institution from one legal order to another. Watson defined a transplant previously as 'the moving of a rule or a system of law from one country to another, or from one people to another'; ${ }^{70}$ Teubner actually disagreed with the term. ${ }^{71}$

In any case, transplants can be divided as follows:

- transplants of necessity;

- transplants of imposition;

- transplants of voluntary choice.

Transplants are highly relevant to legal harmonisation projects, in that such projects introduce new legal information in a number of diverse legal

65 See e.g., H. Barnett, Constitutional and Administrative Law (3rd edn, London, Cavendish Publishing, 2000), pp. 342-3.

66 Constitution of Ireland 1937, arts. 29(5)(1), 29(6).

67 Lord Atkin in Attorney General for Canada v. Attorney General for Ontario [1937] AC 326, has laid down the principle in connection with British law: 'Within the British Empire, there is a well established rule that the making of a Treaty is an executive act, while the performance of its obligations, if they entail alteration of the existing, requires legislative action. The stipulations of a Treaty do not, by virtue of the Treaty alone, have the force of law. If the government of the day decides to incur the obligations of a Treaty which involves alteration of law they have to run the risk of obtaining the assent of Parliament to the necessary statute or statutes'.

68 US Constitution, art. II, s. 2, cl 1.

69 See e.g., D.A.J. Telman, A Monist Supremacy Clause and a Dualistic Supreme Court: The Status of Treaty Law as U.S. Law, Valparaiso University Legal Studies Research Paper No. 13-6 (2013), available at <http://scholar.valpo.edu/cgi/view content.cgi?article51300\&context5law_fac_pubs>.

70 A. Watson, Legal Transplants: An Approach to Comparative Law (Edinburgh, Scottish Academic Press, 1974), p. 21.

71 G. Teubner, 'Legal Irritants: Good Faith in British Law or How Unifying Law Ends up in New Divergences' (1998) 61 Modern Law Review 11. 
systems. Most of the legal harmonisation projects may be perceived as transplants of voluntary choice, even though one could argue that smaller States may not be able to avoid harmonisation transplants in the face of political pressure from other States. Finally, we shall also see that legal transplants theory is also relevant to the proposed comparative factor in the incorporation of harmonised legal norms.

\section{Strategic Considerations}

True harmony is polyphony; it arises out of differences and contrasts, not uniformity. (Pauline C. Westerman, referring to Pufendorf) ${ }^{72}$

The discipline of strategic science is of central importance for the deployment of legal mechanisms, such as the models and factors put forward in our analysis. The act of transposition of foreign law into the domestic sphere is a fine art balancing a number of matters of the real. Scientific considerations must be carefully measured against the domestic realities of the legal system which is to transform foreign legislation into domestic law. The legal norm-to-be-transposed-and-implemented must be, of course, one which reflects the intent of the foreign legislator, i.e. the legislator creating the harmonised instrument in the first place. Nonetheless, the precise configuration of incorporation balancing mechanisms of the norm to be transposed and implemented remains the national sphere's jurisdiction. Harmonised legislation may fail even before it reaches the national legal sphere. Equally, failure or success of the harmonised instrument's implementation is, at least on the face of it, the realm of the national legislator.

The legislator of harmonised legislation is normally the generator of such norm. The national legislator is normally the implementer of such norm. It goes without saying that co-ordination of transposition and implementation activities has to be the case between the national and the extranational by way of excellent communication between them.

72 P.C. Westerman, 'Natural Rights versus Human Dignity: Two Conflicting Traditions' in M. Düwell, J. Braarvig, R. Brownsword and D. Mieth (eds), The Cambridge Handbook of Human Dignity: Interdisciplinary Perspectives (Cambridge, Cambridge University Press, 2014), p. 115. S. Pufendorf, De Jure Naturae et Gentium Libri Octo in The Classics of International Law (C.H. and W.A. Oldfather (trans.), Oxford, Clarendon Press, 1934). 


\section{CONTENT AND PURPOSE OF THE BOOK}

The subject matter of this work has to do with the 'coming together' 73 of legal systems. In particular, the work aims to offer purely theoretical models for the transposition of harmonising norms in order for such a type of norm to be more effectively transposed and implemented, thereby effecting convergence between the recipient implementing legal system and other systems (in the same circle of convergence). The models are relevant to the transposition and implementation of either supranational or international norms. The national legal system stands at the centre of our analysis, ${ }^{74}$ for it is the national legal system which acts as the engine of transposition and implementation of foreign norms into the domestic. Certain of the proposed strategic models are relevant to comparative law, ${ }^{75}$ whilst others are not. There are four strategic models and factors proposed herein:

(1) a general model (relating to the formal and the minor);

(2) a specific model (relating to the major and substantive);

(3) a comparative legal factor (factor of externality, as in a claim of external legal sources);

(4) a socio-legal factor (factor of internality, as in a claim of internal legal sources).

The models are indicative only. Under the general model, ${ }^{76}$ the stress would be on the formal and the minor, i.e. this is a model which aims at uniformity and approximation of the national with the extra-national in matters which do not require major reform. Practically, this strategic model would have to be deployed on the more formal side of things, i.e. for formal and minor changes to the domestic legal order. To use a metaphor, this model could be perceived as the domestic legislator's 'four corners' in the

73 See e.g., B.S. Markesinis, The Clifford Chance Millennium Lectures: The Coming Together of the Common Law and the Civil Law (Oxford, Hart Publishing, 2000); M. van Hoecke, 'The Harmonisation of Private Law in Europe: Some Misunderstandings' in M. van Hoecke and F. Ost (eds), The Harmonisation of European Private Law (Oxford/Portland, Hart Publishing, 2000), p. 9.

74 See e.g., J. Basedow, 'The Effects of Globalisation on Private International Law' in J. Basedow and T. Kono (eds), Legal Aspects of Globalisation (The Hague/ London/Boston, MA, Kluwer Law International, 2000), pp. 4-6.

75 Cf. E. Örücü, 'Looking at Convergence Through the Eyes of a Comparative Lawyer' (2005) 9(2) Electronic Journal of Comparative Law (July), available at <www.ejcl.org/92/art92-1.html>.

76 See Chapter 2. 
transposition of extra-national law into the domestic. A typical example for the deployment of such a model would be the implementation of an international treaty in formal terms. The specific model ${ }^{77}$ is substantially and axiomatically different to the general model. Such a model would be strategically necessitated if and when the national implementer faces significant restructuring of its legal order. This is not just a more specific model in itself; it is a model which specifically necessitates the deployment of a law reform analysis altogether. Unlike the general model, which operates on formalities and minor changes to the order (mainly at the transposition stage), this strategic model is to be deployed where an anacatataxis $^{78}$ to the legal status quo of a system is the case upon the arrival of a foreign harmonising norm. The anacatataxis (or restructuring) can be in a given subject area of law or in the whole of the legal system. Automatically, a constitutional change into the legal order, through the operation of harmonised norms, amounts to what is deemed a legal restructuring (anacatataxis) herein. Beyond this, the specific model's legal restructurings into the domestic order would require specific reforms. Specific reforms would involve special legal arrangements which touch upon the core of a preexisting legal reality in the domestic order. Has this occurred anywhere in the world? It has. The arrival of the European Convention on Human Rights $^{79}$ though the Human Rights Act 1998 represented a major shift in the operations of UK constitutional law. UK constitutional law has been effectively amended by way of direct incorporation of the effects of the ECHR into the UK legal order.

On the other hand, the strategic deployment of a comparative law tool and socio-legal tool could also be contemplated, if the national legislator (as in implementer) deems this appropriate and useful. Yet, the question will always be: when would the deployment of such tools be desirable and appropriate? Perhaps this would have to be best assessed by the needs of the national implementer. After all, national implementing bodies may decide the particularities of the implementation of foreign norms. And yet, these discretionary tools might not be deployed by mere reason of the fact that the national implementer may actually have no discretion in doing so.

In any case, with regard to the proposed comparative factor in the process of incorporation of harmonised legal norms ${ }^{80}$ the national authority is to assess implementations of the same instrument in other jurisdictions.

77 See Chapter 3.

78 Greek for whole reshuffling or restructuring.

79 Hereinafter 'ECHR'.

80 See Chapter 4. 
Arguably, this may be an arduous task (for a number of objective reasons, e.g. language barrier, timeframes, cultural differences, etc.). Yet, the very same arduous task might prove quite beneficial for the legislator having to implement the harmonising instrument. This factor is a syncretic factor. Quintessentially, it asks the national implementer to proceed with a comparison of implementations in certain other affiliated ${ }^{81}$ jurisdictions. The rationale of utilising the comparative factor would be one that is based on taking note of good practice from abroad, when it comes to the same exercise of implementation. The socio-legal factor is different. Whereas the comparative factor asks for the national implementer to proceed with an enquiry of implementations elsewhere, the national implementer, in the case of the socio-legal factor, proceeds with an internal examination of the domestic legal order in the first place. The rationale would be one which suggests that the implementation of a harmonising norm need not be wholly foreign, peculiar and abstract to the domestic system. If it is, the system could, in principle, be allowed a certain degree of flexibility or deviation in the implementation exercise. Such deviations would not necessarily need to oppose the spirit of the harmonised norm. Equally, under the socio-legal factor, a harmonised norm may be rejected, if it is wholly unacceptable to the domestic legal order (even though this is something which ought to be affirmed at the extra-national level). Finally, it is contemplated that the parallel utilisation of the comparative factor and the socio-legal factor is wellpossible (if not desirable). Thus, the two factors are not mutually exclusive.

It will be maintained that the parallel usage of any of the four strategic elements of the proposed thesis already constitutes a full, ideal and adequate overall framework for the national implementer to proceed with in carrying out the exercise of transposing harmonised norms into the domestic sphere. Nonetheless, the deployment of these strategic models and approaches, with or without modification, as put forward herein, would depend exclusively on the national implementer. The national implementer alone normally decides the particularities of the transposition exercise (unless, of course, the transposition exercise does not offer any degree of discretion, in which case, the models proposed herein become wholly obsolete even as mere considerations). Thus, these are optional models. These are models which the national implementer can use and/ or the extra-national legislator could propose. Additionally, the national implementer could concurrently deploy more than one strategic approach. In comparative law, it has been argued, for instance, albeit in a different

81 See 'Affinitatis Formula' in Chapter 4 for an explanation as to what constitutes an affiliated legal system. 
context, that the parallel deployment of more than one model is possible. ${ }^{82}$ As always, the deployment of more than one strategic approach, or, indeed, of any number of strategic approaches, will ultimately have to be decided on a case-by-case basis. Even then, the national implementer may follow their own known approaches, because, arguably, they still retain a considerable degree of sovereignty. In actual terms, however, the question will have to be one of practicalities. This means that a case of implementation might be followed by any of the approaches here based on a resources consideration (time, scientific capital, familiarisation with suggested approaches, and so on and so forth).

\section{Unifying Hypothesis}

The hypothesis of the proposed thesis is its first parameter. There are two facets behind the unified hypothesis of the thesis put forward: both of them are based on factuality, thereby enhancing the validity of the thesis altogether. First is the fact that legal systems face minor and major changes in themselves (whether through domestic legislation or through convergent and harmonised legislation). Secondly, there is the established antithetical pattern between internality and externality of law, i.e. law can be examined through the lenses of internal sources and/or through external ones.

The hypothesis is a unifying one, i.e. it effectively encompasses all of the strategic approaches of the proposed thesis into one. Perhaps, one could proceed further by arguing that the first part of the unified hypothesis (division into minor and major matters of law) could be perceived as the main mode of analysis, whereas the second part (analysis through reference to internal and external sources) of the unified hypothesis could be taken to be the auxiliary mode of analysis. If so, depending on the national implementer's exercise, it would be for the legislator to choose the deployment of the main models, whether selectively or wholly. Equally, on occasion, the national implementer could proceed further by basing his analysis on the proposed auxiliary forms of analysis herein.

\section{Effectiveness}

There is a professional sort of obsession of lawyers with the effectiveness of the law. An economist would readily pinpoint the necessity for efficient

82 Cf. Zweigert and Kötz, An Introduction to Comparative Law, n. 31 above, at 6-12; H. Collins, 'Methods and Aims of Comparative Contract Law' (1991) 11 Oxford Journal of Legal Studies 396, at 398. 
laws, whereas a lawyer would (normally) be interested in the law being effective and causing effect in the first place. This being the case, one takes it that the purpose of the proposed strategic approaches herein is to effect convergence as between legal systems. Practically, the question of effectiveness becomes a question of implementation, i.e. the models aim at the implementation of harmonised law (and through this at the convergence of laws as between different legal systems). The question of effectiveness is one which arises in two different ways, such ways being relevant to the strategic models proposed:

- a functionalist approach (whereby the specific models proposed effectively serve specific functions);

- a specialist approach (whereby the totality of the specific models proposed promotes Adam Smith's idea of 'division of labour'). ${ }^{83}$

Let us briefly elaborate on each of the above. First, with regard to the functionalist approach as to effectiveness, it is the case that, by definition, the strategic model of minor changes, changes brought about by way of harmonised law, should effect minor changes to the system, whereas the strategic model of major changes should effect major changes to the system. As stated previously, the comparative strategic model is one which detects transposition information and implementation matter in relevant legal systems (as opposed to seeking to detect such materials from an indefinite amount of legal systems). Furthermore, the socio-legal model seems prima facie to satisfy the test of effectiveness, in that it seeks to transpose foreign norms by observing domestic socio-legal realities, if and when this is possible. ${ }^{84}$

Secondly, when it comes to the effectiveness of the proposed models and factors, Adam Smith's classical thesis of 'division of labour' is of relevance. Division of labour is the theory which suggests that different economic actors perform different economic tasks, thereby potentially increasing the productivity and effectiveness of the economic system in which such actors perform. Specialised labourers ought to produce better results in given specific tasks. A labourer alone may perform a number of specialised functions. Yet, if these specialised functions are performed by

83 A. Smith, An Inquiry into the Nature and Causes of the Wealth of Nations (1776), Book 1, Ch. 1, para. 1, reproduced in R.H. Campbell, A.S. Skinner and W.B. Todd (eds), An Inquiry into the Nature and Causes of the Wealth of Nations (Oxford, Clarendon Press, 1976), p. 13 (in the original text).

${ }_{84}$ Otherwise, the factor may be used as a call for renegotiation of harmonised norms between the national and the extra-national. 
and divided into a number of specialised labourers, such a division may result in greater efficiencies. Just as four specialised 'labourers' ought to produce greater results in dealing with the same subject matter (as opposed to a single labourer performing a number of different functions in the same matter), it is submitted that the four strategic models proposed ought to result in effectiveness of implementation of foreign harmonised norms by mere reason of the fact that they are specialised models serving specialised functions in the process. Nonetheless, these specialised labourers, these specific strategic models, ought ultimately to effect the overall aim of implementing and transposing harmonised law. Thus, the effectiveness of the models arises not only by mere reason of the fact that these are specialised tools for specific tasks but also, more importantly, out of the fact that their combination ought to produce better results in itself. A classical principle of economics, thus, finds itself being of central importance for the models proposed. Accordingly, a 'humble economic principle formerly relegated to mean or ignoble employments now finds itself connected with philosophical discussion of the highest order' ${ }^{85}$

Adam Smith was not the first author to deal with the division of labour thesis, even though he was the one who perfected it to a considerable extent. Smith and a number of other scholars before him (Plato, Xenophon, Mandeville and Hutcheson, to name only certain of the leading personalities that dealt with the thesis in question) argued the philosophical as well as the economic foundations of the division of labour thesis. Practically, they argued, in one way or another, it is more efficient to proceed with specialised tools in a given exercise than having to proceed with a single tool addressing each and every one of the specific tasks thereof. ${ }^{86}$ Specialisation and diversification define the exercise. ${ }^{87}$ The essence of the division of labour

85 M.L. Myers, 'Division of Labour as Principle of Social Cohesion' (1967) 33 Canadian Journal of Economics and Political Science 432, at 434.

86 This approach occurs not only in economics but also in other disciplines as well, e.g. in biology and in computer science engineering. See e.g., L.M. Wahl, 'Evolving the Division of Labour: Generalists, Specialists and Task Allocation' (2002) 219 Journal of Theoretical Biology 371; J. Rettner, 'Multi-core to the Masses', paper presented at 'Parallel Architectures and Compilation Techniques, PACT 2005', 14th International PACT Conference, St Louis, Missouri, 17-21 September 2005; O. Takahashi, 'The Circuits and Physical Design of the Synergistic Processor Element of a CELL Processor' in 2005 IEEE Symposium on VLSI Circuits, Digest of Technical Papers (2005), pp.20-3; D.C. Pham et al., 'Overview of the Architecture, Circuit Design, and Physical Implementation of a First-generation Cell Processor' (2006) 41(1) IEEE Journal of Solid-State Circuits (January) 179.

87 W. Cheng and X. Yang, 'Inframarginal Analysis of Division of Labor: A Survey' (2004) 55 Journal of Economic Behavior and Organization 137, at 143. 
thesis is based on the deployment of specialised and diversified forces into a given exercise. However, such a deployment of specialised labourers does not occur in abstracto. On the contrary, the division of labour thesis seems to suggest that co-ordination follows specialisation and diversification. In the context of this monograph, this would in practice entail the parallel deployment of more than one model ('specialised labourers') suggested in order for the overall task to be achieved: the task being the implementation of a foreign harmonised norm to the point of convergence of the domestic order with the extra-national. Petty, in this respect, had once noticed that Dutch shipyards are more effective in their output, when specialised teams of workers perform specialised tasks in the producing of ships. Equally, in our thesis, the task of implementing harmonised norms into the domestic order is one which is perceived as an overall project to be achieved. This is a project with specialist extensions. Close to Smith's call for specialised, diversified and co-ordinated resources, it is opined that the specific models herein amount to such resources, thereby, at least in theory, effecting a greater degree of effectiveness in the exercise of implementing harmonised law.

\section{Division of Labour}

In other words, a stratagem from economics is deployed here to assert effectiveness. To put this in perspective, classical economics theory broadly suggests that to achieve the overarching aim of anything, one has to first fragment, diversify and deploy resources for the aim to be achieved (division of labour) ${ }^{88}$ Effectively, the task is one of strategic deployment of available resources. In more practical terms, the 'specialised labourers' (models) proposed aim to bring about effective implementation of convergent law, thereby bringing, in turn, 'effective convergence' as between legal systems in the same circle of harmonisation. The following division of labour then seems to be true for the purposes of our thesis:

(1) first 'labourer': the general model;

(2) second 'labourer': the specific model;

(3) third 'labourer': the comparative legal factor;

(4) fourth 'labourer': the socio-legal factor.

These four labourers are effectively the equivalent of four faculties of knowledge. Such faculties can be deployed in the implementation of

88 T. Negishi, 'Adam Smith's Division of Labor and Structural Changes' (2000) 11 Structural Change and Economic Dynamics 5, at 6. 


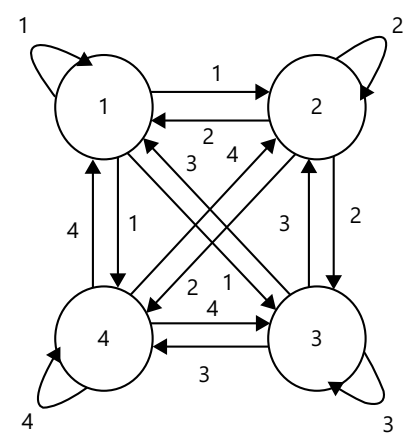

Figure 1.2 Division of labour in relation to the models and factors proposed

harmonised law. In cognitive terms, one speaks here of the faculty of generalities and formalities; the faculty of particularities or major matters; the faculty of legal externalities; and the faculty of legal internalities. Our 'labourers' or 'faculties' can be used in conjunction with one another (see Figure 1.2). This is not a strict necessity, however. Ultimately, the question of the precise deployment of any of these faculties will mostly depend on the national implementer. Importantly, the proposed models are to be perceived as faculties of knowledge as opposed to models stricto sensu by reason of the fact that they are actually configurations of the real. In any case, in line with Adam Smith's division of labour thesis, it should be noted that the models are perceived as specialised resources with an overarching scope, that of convergence of legal systems. So too, following Adam Smith's thesis, the overarching purpose can be one which asks for the effective implementation of harmonised law. The models present us with a number of possibilities. Thus:

[consider] [t]he solution to a difficult game (e.g. solving a Rubik's cube or playing chess). An effective solution is a long sequence of moves, each of which is chosen out of a set of possibilities. ${ }^{89}$

As a last remark, the four 'labourers' do not have to be used as they are prescribed herein. Our labourers are flexible. The models, thus, are modifiable and open to adjustment (as any theoretical model probably

89 L. Marengo and G. Dosi, 'Division of Labor, Organizational Coordination and Market Mechanisms in Collective Problem-solving' (2005) 58 Journal of Economic Behavior and Organization 303, at 309 (original emphasis). 
should be). After all, as Adam Smith posited, inter alia, the dexterity ${ }^{90}$ of labourers improves over time. It is, therefore, opined that the proposed models will have to be adjusted, modified and improved upon, for they are theoretical constructs.

\section{Geographical Scope and Miscellaneous Legal Parameters}

It is understood that the proposed thesis implies a political centre of legal harmonisation initiatives. Furthermore, whereas it is contemplated that bottom-up approaches are well-possible, the analytical model herein actually implies an extra-national (whether supranational or inter-governmental) organisational structure initiating harmonised legal norms. Such organisation takes the form of a prototype legal authority, even though one could not exclude the theoretical possibility that legal systems in a circle of convergence approximate their laws without the need to create and/or refer to such a proposed authority. Practically, the proposed strategic models imply a legal harmonisation authority issuing convergent law, which national legal systems have to transpose and implement. In this perception, the authority understands the national legal systems as being sovereign. Nonetheless, a certain degree of their sovereignty is moderated due to the fact that they have devolved legislative powers to the suggested prototype authority.

\section{Global Model Implications}

There are no theoretical or practical limitations to the globality of the proposed analytical model. It is understood, however, that a global model of convergence would come with challenges of scale due to its geopolitical ambit. The opposite is also true: the globality of the analytical model does not make the model one which is exclusively global. If so, one understands that there is a clear theoretical possibility for the proposed strategic models to apply at the regional level. After all, models of legal convergence can occur at the more pragmatic level of regional convergence of laws. In any case, the analytical model herein is one which presents us with 'an alliance of globalism and regionalism'. ${ }^{91}$ Co-extensively, as convergence of laws can occur at the global or regional level, both international law and European law will be used for the analytical purposes of this monograph.

90 E.G. West, 'Adam Smith's Two Views on the Division of Labour' (1964) 31(121) Economica, New Series (February) 23.

91 See e.g., P.L.C. Torremans, Legal Convergence in the Enlarged Europe of the New Millennium (The Hague/London/Boston, MA, Kluwer Law International, 2000), p. 28. 


\section{Employment of Certain Features of European Legal Convergence and Swiss and US Models of Internal Legal Alignment}

Constitutionally, the overall theoretical model of this analysis draws matter from certain European, American and Swiss legal experience. First of all, the European model of convergence (with its deficiencies and drawbacks) is, generally speaking, a good starting point for one's commencement of analysis with strategies as to implementing harmonised forms of law (albeit at the regional level). In any case, the European model of legal convergence is interesting for a number of reasons: first, the European Union (EU) model is to date the leading example of regional convergence in the world; after the collapse of the Union of Soviet Socialist Republics (USSR), it is the only supranational law-making union of states in the world. ${ }^{92}$ Secondly, Europe is interesting, as it is a great mosaic of rather diverse people and cultures. This diverse spectrum of peoples, largely united by Christianity and the rather remote concept of European culture, perhaps even by the love of man and all that human nature represents, has a certain appeal. Thirdly, there is considerable legal ambition in Europe. For instance, the EU to this day remains the most ambitious legal structure $^{93}$ of direct legal convergence between sovereign States. Despite the fact that the European project is in crisis as these lines are written, that dream of the fathers of modern Europe, just after the Second World War, for a Europe largely free, stable and peaceful is still very much alive. Fourthly, the mechanisms of legal convergence in Europe, through Directives and Regulations, are of particular interest to the analytical model herein. This is the case, because due to the varied nature of legal instruments such as Directives and Regulations, such legal instruments may not only be of benefit to the extra-national legislator but also to the national implementer. Fifthly, Europe is also, to this day, the only continent which has a genuine and dual ${ }^{94}$ form of legal convergence mechanism (materialising through the Council of Europe and the EU). ${ }^{95}$ As stated, the deficiencies

92 Cf. H.P. Glenn, 'North America as a Medieval Legal Construction' in M. Bussani and U. Mattei (eds), The Common Core of European Private Law (The Hague/London/New York, Kluwer Law International, 2003), pp. 51, 59; and T.C. Hartley, European Union Law in a Global Context: Text, Cases and Materials (Cambridge, Cambridge University Press, 2004), p. 5.

93 Hartley, European Union Law in a Global Context, n. 92 above, at 3.

94 M. Delmas-Marty, Towards a Truly Common Law (Cambridge, Cambridge University Press, 2002), pp. 168, 171.

95 Lenaerts and Van Nuffel, Constitutional Law of the European Union, n. 50 above, at 23-6 (Council of Europe integration path), 41-65 (EU integration path). 
of the EU model are otherwise quite apparent (e.g. the democratic deficits of the Union). Nonetheless, it would be fair to suggest that there is a certain merit ${ }^{96}$ in the usage of European legal material as a whole; with all its drawbacks, Europe is still the most effective ${ }^{97}$ example of direct legal convergence machineries with special judicial arms to this effect (European Court of Human Rights and Court of Justice of the European Union).

Yet, it would also be appropriate, taking a comparative approach, to look beyond Europe. There are other legal realities which have come up with excellent models of internal legal alignment. The US and Swiss models of federal and confederative law are particularly beneficial for the purposes of our analysis. This is true by reason of the fact that such models of internal legal alignment (as between the Federation and the States in the United States and as between the Confederation and the Cantons in Switzerland) provide certain analogical features for the purposes of our analysis. Clearly, there are differences between Europe's supranational and extra-national features of legal convergence and the particulars of the US and Swiss models. For instance, the United States is a federal structure, whereas the EU and the Council of Europe are characterised by supranationalism and inter-governmentalism, ${ }^{98}$ the European Union taking the form of an association of mostly sovereign States. However, as in the European case with European law overriding domestic laws in a number of matters, federal US law, in its areas of competence, seeks to override and does override State law. Equally, Swiss confederative law seeks to align and does align Canton law; additionally, certain comparative aspects of the US and the Swiss models are of particular interest. This

96 See nn. 92 and 93 above. See also certain critical remarks of scholars in relation to the American human rights protection system vis-à-vis European experience, e.g. A.H. Robertson and J.G. Merrills, Human Rights in the World (4th edn, Manchester/New York, Manchester University Press, 1996), p. 156, where they state that '[i]t follows that a member of the Inter-American Commission on Human Rights would be impressed by the functioning of the European system'. Also, with regard to the Inter-American Court on Human Rights, it should be noted that individual citizens of a Member State of the Organisation of American States cannot take cases directly to the Court, as is the case under the European human rights system.

97 The effect of EU law, for instance, is felt in the lives of 500 million people, whereas the effect of the ECHR is felt in the lives of 800 million people. These are by far the most expansive and effective models of regional legal convergence anywhere in the world.

98 See e.g. P. Craig, and G. De Búrca, EU Law: Text, Cases and Materials (3rd edn, Oxford, Oxford University Press, 2003), pp. 3-4; D. Chalmers, G. Davis and G. Monti, European Union Law (3rd edn, Cambridge, Cambridge University Press, 2016), pp. 2, 14-19. 
being the case, these types of overriding effects do not quite exist in the case of Europe. In this respect, it is noted that EU law's primacy over Member States' laws is still a subject largely in flux, even if the situation in recent decades has developed in the right direction. Otherwise, there are significant differences between the European approach and the US and Swiss models. For instance, there is no such thing as federal legislation in Europe (at the Pan-European level); nor are there such things as model acts or uniform laws. ${ }^{99}$ In EU legislation, the sensitive touch of the Swiss confederative legislator with regard to respecting domestic sociological patterns of the implementers of confederative law seems to be missing. In this respect, Article 46 of the Swiss Constitution is particularly illustrative. ${ }^{100}$ Thus, unlike the situation in Switzerland, both the EU and the US models have largely failed to provide crystal-clear statutory provision as to how harmonising or federal law, respectively, can best accommodate the domestic realities of their constitutional subjects (i.e. States and Member States respectively in the United States and in the EU).

\section{Correspondence Principle}

Strategic considerations are, inter alia about model building. Model building is generally a perfectly acceptable enterprise in Academia. ${ }^{101}$ However, there are a number of particularly significant considerations in respect of model-building. First, a theoretical model has to be compliant with one's perception of reality. ${ }^{102}$ Thus, a model gains its 'credibility from its correspondence with one's perception of reality'. ${ }^{103}$ Samuel seems to at least imply that such a reality does not have to be an objective one

99 See also R. Hyland, 'The American Experience: Restatements, the UCC, Uniform Laws, and Transnational Coordination' in A. Hartkamp, M. Hesselink, E. Hondius, C. Joustra, E. du Perron and M. Veldman (eds), Towards a European Civil Code (3rd edn, New York, Kluwer Law International, 2004), p. 53 et seq.

100 In particular, original art. 46(2) of the Swiss Constitution 2000 on the implementation of federal laws by the Cantons reads as follows: 'The Federation leaves the Cantons as much organizational scope as possible and takes into account the peculiarities of Cantons'.

101 See e.g., 'The Architecture of Theories' in J. Buchler (ed.), The Philosophy of Peirce: Selected Writings (London, Routledge, 1940, reprinted in 2000), pp.315-23.

102 G. Samuel, 'Epistemology and Comparative Law: Contributions from the Sciences and Social Sciences' in M. Van Hoecke (ed.), Epistemology and Methodology of Comparative Law (Oxford/Portland, OR, Hart Publishing, 2004), p. 44. But cf. G. Samuel, Epistemology and Method in Law (Aldershot, Dartmouth, 2003), p. 120.

103 Samuel, 'Epistemology and Comparative Law', n. 102 above, at 44. But cf. Samuel, Epistemology and Method in Law, n. 102 above, at 120. 
(if such a thing as objective reality exists, of course). It follows that the model's correspondence with the world of objectivity does not have to be a perfectly strict one. If so, the strategic models put forward in this analysis do not have to be 'objective' per se. Yet, such an approach must be the subject matter of certain justification. For instance, one could argue that theoretical modelling in a given area of knowledge may have not taken place before. Or, more interestingly, with particular regard to our analysis, one could certainly argue that the totality of the models in the analysis form $a$ typology of models (as opposed to them forming the typology of relevant models). Finally, one could maintain that the models and factors negotiated operate on rationalism, as the models and factors herein are the subject matter of justification and conditioning.

Law, on the other hand, is par excellence the thing that wants a reason'. ${ }^{104}$ The models and factors presented should, therefore, be further justified. Samuel seems to opine that theoretical models have to be justified and mutatis mutandis objectified, aside from this 'correspondence principle'. As he put it:

Thus a model which plots the movement of comets and predicts when and where they will be at any given moment is likely to be treated seriously if the predictions can be independently verified by observation. However a model can also gain its validity from its own internal coherence... A third method of verification is consensus. A model or indeed theory will gain its force and credibility if members of a specified community are agreed amongst themselves that it is valid. ${ }^{105}$

The process of 'objectifying' subjective theoretical models can be particularly arduous. However, an important point to be made here is the fact that the models are based on observation. ${ }^{106}$ So too, observation can be perfectly verifiable, when examples are real (as in most cases these have been) and they, in turn, reflect one's perception of reality, that is, the author's. Yet, even where theoretical examples have been used, observation has still been the case, for otherwise the use of theoretical examples would be taken to be obsolete, an otherwise repugnant and absurd approach

104 J. Buchler (ed.), The Philosophy of Peirce: Selected Writings (London, Routledge, 1940, reprinted in 2000), p.318. Cf. also the well-known maxim: ratio legis est anima legis.

105 Samuel, 'Epistemology and Comparative Law', n. 102 above, at 44 (original emphasis). In the same work, see also Samuel's analysis on the virtuality of models, his distinction between virtual and actual facts, and the 'French candidate in the Paris constituency' metaphor at 45-6 and 74.

106 Cf. Buchler, The Philosophy of Peirce: Selected Writings, n. 104 above, at 150. 
in legal theory (a contrario argumentation). To recap, observation of examples comes from the real and the hypothetical. In the former case, observation occurs by definition; in the latter case, observation occurs by way of propositional logic. Thus, on the real examples side of things, A is observed in order for B to be realised, whereas on the hypothetical side of things, $\mathrm{Y}$ is used as an example, in order for $\mathrm{Z}$ to be proposed. Finally, with regard to the internal aspect of the models and factors presented, it is opined that the models and factors put forward amount to a complete and adequate overall system of logic, such models being able to be used interchangeably but, equally, being open to adaptation, as they come with a certain subjective character in their essence.

\section{Propositional Logic}

As stated, the strategic models are discretionary, modifiable and operational on propositional logic. Propositional logic, at its simplest, takes the following form: if $a$, then $b .{ }^{107}$ Let us proceed on the basis of propositional logic by utilising the 'general model' of our analysis. Under such model, the world of implementing harmonised law through formalities and minor amendments to domestic law is one which recognises the existence of 'uniform' and 'directive' forms of harmonised law. As such, the world of harmonised law, at least according to our proposed general model, takes the form of either $a 1$ or $a 2$, where $a 1$ amounts to uniform harmonised law and $a 2$ amounts to instructive or directive harmonised law. ${ }^{108}$ Thus, $a$ similis, the general model's application proceeds on the basis that either $a 1$ or $a 2$ operate. A contrario, the non-occurrence of either $a 1$ or $a 2$ makes the application of the model (b) obsolete (thus, if not $a 1$ or $a 2$, then not $b$ ). ${ }^{109}$

Reasoning is the crystallisation of logic. Reasoning, as a whole, takes

107 See e.g., H. Pospesel, Introduction to Logic: Propositional Logic (Englewood Cliffs, NJ, Prentice-Hall, 1974); Samuel, Epistemology and Method in Law, n. 102 above, at 106. See also the 'connective logic' of Chrysippus of Soli whereby "With words like "and", "or" and "if . . . then", different statements can be joined together and the truth of the whole will depend exclusively on the truth of the parts'. (Example: Either Muhammad will go to the mountain or the mountain will go to Muhammad. Muhammad did not go to the mountain, therefore the mountain went to Muhammad) and the later but more refined 'propositional calculus' under Frege in D. Cryan, S. Shatil and B. Mayblin, Introducing Logic (Royston, Icon Books, 2004), pp. 8, 19.

108 See e.g., Delmas-Marty, 'Comparative Law and the Internationalisation of Law in Europe', n. 51 above, at 252.

109 This is also known as the 'arrow out' rule in propositional logic ('The Arrow Out Rule: From a conditional and a statement identical to its antecedent derive a 
one of the following three forms: deduction, induction and abduction. ${ }^{110}$ Deduction is the process of rationalisation from general premises to specific premises. Deduction is, thus, inference in which the conclusion is of no greater generality than the premises thereof. ${ }^{111}$ Induction is the process of rationalisation from specific premises to general premises. ${ }^{112}$ Under inductive reasoning, a general conclusion is reached based on the specific premises of a given argument. Nonetheless, inductive reasoning does not ensure or guarantee the conclusion reached, in that the conclusion is normally of greater generality than the premises. ${ }^{113}$ Finally, abduction (or retroduction) is the process of rationalisation whereby the conclusion is drawn by way of inference to the best explanation(s). Such inference occurs through the identification of a given phenomenal pattern and by suggestion of a hypothesis. ${ }^{114}$ Normally, the hypothesis made is adapted to facts. ${ }^{115}$

Overall, the strategic models in this monograph proceed on deductive and abductive reasoning. It is submitted that the general strategic model is one which proceeds on deductive reasoning, ${ }^{116}$ as the socio-legal factor does. ${ }^{117}$ The restructuring model (or the model catering for major changes to the systems through harmonised law) and the comparative legal factor

statement identical to its consequent'). See Pospesel, Introduction to Logic, n. 107 above, at 13-19.

110 See e.g., A.W. Burks (ed.), Collected Papers of Charles Sanders Peirce, Science and Philosophy, vol. 7 (Bristol, Thoemmes Press, 1998), p. 61.

111 A typical example of deductive reasoning is the following: All men are mortal. Socrates is a man. Therefore Socrates is mortal.

112 A typical example of inductive reasoning would be: This raven is black. That raven is black. Therefore, all ravens are black.

113 Ibid.

114 A typical example of abductive/retroductive reasoning is: The grass is wet. But if it rained, wet grass is observed as a matter of course. Therefore, there is a reason to suspect that it rained. Alternatively, the surprising fact, $\mathrm{C}$, is observed. But if $\mathrm{A}$ were true, $\mathrm{C}$ would be a matter of course. Therefore, there is a reason to suspect that A is true. See Buchler, The Philosophy of Peirce: Selected Writings, n. 104 above, at 151 .

115 Burks, Collected Papers of Charles Sanders Peirce, n. 110 above, at 67.

116 See e.g. 'All implementations of convergent instruments of law fall in the first instance within the general model. This is an implementation of a convergent instrument of law. Therefore, the implementation of this convergent instrument of law falls in the first instance within the general model' (Deduction).

117 See e.g. 'All implementations of convergent instruments of law interfering with internal sources of law could mutatis mutandis fall within the application of the socio-legal factor. This is an implementation of a convergent instrument of law which interferes with internal sources of law. Therefore, the implementation of this convergent instrument of law could fall in the first instance within the application of the socio-legal factor' (Deduction). 
proceed on abduction by operation of minor hypotheses thereto. For instance, the hypothesis with regard to the restructuring model suggests that major changes through harmonised law result in special arrangements in the domestic sphere. ${ }^{118}$ The hypothesis with regard to the comparative legal model is that there is practicality and convenience for the legal system, when it is in the process of comparing implementations of harmonised law in related legal systems. ${ }^{119}$

Consideration must be given to the fact as to whether the abductive elements of the analysis fall into the wider category of inductive reasoning. It is submitted that, whereas one could actually suggest that the abductive elements of the analysis could be re-categorised into legal models, which proceed on induction, that ought not to be the case. There are three clusters of reasoning submitted in this respect. First, is the fact that the author intends the models to formulate abductive understandings as to the best inference of explaining things (as opposed to the author reaching general conclusions under the exemplifications provided); thus, it is not only the fact that these models operate as per exemplifications and as per a hypothesis made but also the fact that these models provide us (as abductive models) the best inference as to explaining things-to-be in the subject area of their investigation. Secondly, the qualitative conferment of a number of examples in the abductive parts of the analysis would probably serve abduction better than they would serve induction. The reason for this is the fact that inductive rationalisation has normally to be tested through a plethora of examples (or case studies). Arguably, such a number of examples would have to be great (law of large numbers). Thus, simply because one observes four black ravens in a given environment, this does not mean that all ravens all over the world are black; especially, when we know that actually there are white ravens in Japan. ${ }^{120}$ Thirdly, a limited number of situations observed in the past does not pre-establish or guarantee repetition of the same in the future. Co-extensively, the comparative legal factor and the restructuring model are not to be perceived as automatically applicable as inductive models for applying in future situations. In logic,

118 See e.g. 'The specific (restructuring) model applies as per exemplifications. But if there were special arrangements in the implementation of major changes convergent law (hypothesis), then the model would be a matter of course. Therefore, there is reason to suspect that the model's hypothesis is true (Abduction).

119 See e.g. 'The comparative legal model applies as per exemplifications. But if there were practicality and convenience in comparing implementation of convergent law in related legal systems (hypothesis), then the model would be a matter of course. Therefore, there is reason to suspect that the model's hypothesis is true (Abduction).

120 Cryan, Shatil and Mayblin, Introducing Logic, n. 107 above, at 116. 
simply because something is observed in the past does not mean that this should be valid in the future, whether through theoretical modelling or not (post hoc ergo propter hoc fallacy). ${ }^{121}$

\section{Choice of Models}

On the basis that a national implementer would consider the precise ways of transposing and implementing harmonised law, the question will be one of choice of methods. Theoretically, the choice of methods will almost invariably be dependent on formalities and/or major restructurings behind harmonised law application, with or without the deployment of comparative legal and socio-legal considerations. These are all strategic considerations, which are covered through the proposed models and factors herein. Nonetheless, the precise choice of methods will largely depend on the following four considerations:

(1) practicality of chosen model in relation to the particular transposition and implementation exercise (on a case-by-case basis);

(2) the nature and the character of the legal system per se;

(3) the political will and the scientific freedom to proceed beyond certain pre-established approaches in the matter; and

(4) the impact which harmonised legislation may have on the legal system.

A qualifier for our analysis is also the fact that the proposed models mainly relate to the legislative implementation and judicial enforcement of harmonised norms. It is understood that the executive/administrative implementation of harmonised norms is normally a separate matter, the particularities and practical implications of which could be best analysed and addressed by public administration experts and scholars. Thus, any considerations on purely executive and administrative matters are seen as rather deviating from the legal perspective. Analogically, however, the models could be deployed in matters which touch upon executive and administrative considerations (see, for instance, comparative administrative and executive approaches and the related).

121 Burks, Collected Papers of Charles Sanders Peirce, n. 110 above, at 67: 'But it is Abduction, not Induction, and proves nothing but the ingenuity with which the hypothesis has been adapted to the facts of the case. To take this for Induction, as a great proportion of students do, is one of the greatest errors of reasoning that can be made. It is the post hoc ergo propter hoc fallacy, if so understood'. 